Rok XV (2020) | 2 (30) | S. 91-104

https://doi.org/10.12797/LV.15.2020.30.08

\author{
Kinga Tutak • \\ Uniwersytet Jagielloński, Kraków \\ kinga.tutak@uj.edu.pl
}

\title{
INSTANCJE NADAWCZO-ODBIORCZE W TRAKTATACH STAWIARSKICH Z XVI I XVII W.
}

Słowa klucze: instancje nadawczo-odbiorcze, traktaty stawiarskie, Olbrycht Strumieński, Stanisław Strojnowski

Keywords: sender-recipient instances, treatises on ponds, Olbrycht Strumieński, Stanisław Strojnowski

Stawiarstwo, czyli hodowla ryb w stawach, ma na ziemiach polskich długą tradycję, sięgającą drugiej połowy XII w. (Dobrowolski 1995: 11). W średniowieczu polskie stawiarstwo było uznawane za najnowocześniejsze w Europie (obok stawiarstwa czeskiego). Najstarsze i największe gospodarstwa rybne mieściły się w dorzeczach górnej Wisły i Odry, a także nad środkową Bzurą. W drugiej połowie XVI w. w krakowskiej oficynie Łazarza Andrysowica ukazało się pierwsze napisane w języku polskim ${ }^{1}$ dzieło poświęcone gospodarce stawowej. Był to liczący 68 kart w czwórce traktat Olbrychta Strumieńskiego zatytułowany O Sprawie Sypaniu / Wymierzaniu

1 Wcześniej, bo w roku 1547, Andreas Winkler (Vinglerus) wydał we Wrocławiu pracę Iani Dubravii de piscinis ad Antonium Fuggerum Jana Skály z Doubravky a Hradiště, zwanego z łacińska Dubraviusem, przetłumaczoną około roku 1600 na język polski przez księdza Andrzeja Progę (Inglot, Nyrek 1960: 254). Dzieło Dubraviusa ma jednak nieco inny charakter niż późniejsza o 26 lat praca Olbrychta Strumieńskiego. Jest to traktat naukowy o gospodarce rybnej, w którym wiadomości praktyczne uzupełniały jedynie wiedzę teoretyczną, były drugoplanowe. Według Stefana Inglota i Aleksandra Nyrka „pracę czeską pisał uczony znający gospodarczą i przyrodniczą literaturę starożytną i wczesnośredniowieczną [...]; pracę polską pisał ekonom i mistrz stawiarski [...]" (ibid.: 255). 
I i Rybieniu stawów: także o Przekopach / o Ważeniu i prowadzeniu Wody. Ksiażki wszystkim gospodarzom potrzebne ${ }^{2}$ (1573). Olbrycht Strumieński z Mysłowic był jednym z najzdolniejszych mistrzów stawiarskich. Pod jego nadzorem budowano stawy na Górnym Śląsku, w Małopolsce i prawdopodobnie także na Rusi Czerwonej (Nyrek 1987: XI), czyli na terenach, na których gospodarka stawowa rozwijała się bardzo dobrze, i to już od średniowiecza (ibid.: VI-VII). Taki stan rzeczy spowodowało kilka czynników, a więc znaczna odległość Śląska i Małopolski od morza, brak większej liczby jezior na tych ziemiach, rozwój miast, wreszcie ściślej wówczas przestrzegane posty (ibid.). Jednocześnie istniało duże zapotrzebowanie na fachową, ale i przystępną książkę w języku ojczystym dotyczącą gospodarki stawowej. Odpowiadając na zainteresowanie czytelnicze, Andrysowic wydał pracę Strumieńskiego, a właściwie jego notatki sporządzone w toku długoletniej praktyki, zalecające najlepsze rozwiązania w zakresie urządzania i prowadzenia gospodarstw stawowych (ibid.: XII). Zapotrzebowanie na szerzej dostępną literaturę fachową nie skończyło się na XVI w., o czym świadczy wydanie na początku XVII w. przez Bazylego Skalskiego Opisania Porządku Stawowego / I Przestróg niektórych domowego Gospodarstwa / z pilnościa uczynione / od Stanisława Strojnowskiego z Strojnowa / Ku czytaniu i wiadomości wszelakim stanom wielce potrzebne i pożyteczne $e^{3}(1609)$. Obie prace reprezentują piśmiennictwo użytkowe, ściślej: staropolskie poradniki lub kompendia wiedzy aktywnej (Balcerzan 1999: 366), podejmują również tę samą problematykę, natomiast opuściły prasy drukarskie w odstępie 36 lat. Celem artykułu ${ }^{4}$ jest porównanie strategii nadawczo-odbiorczych realizowanych w tych dziełach. Jest to zadanie badawcze tym bardziej uzasadnione, że w nauce polskiej opracowanie S. Strojnowskiego zostało uznane za plagiat dzieła Strumieńskiego ${ }^{5}$. W obu traktatach będę poszukiwała

2 Dostępny w wersji elektronicznej http://www.dbc.wroc.pl/dlibra/doccontent?id=3351.

3 Brałam pod uwagę wydanie traktatu Strojnowskiego z 1609 r., przedrukowane w: Gawarecki, Kohn 1861. Zygmunt Gawarecki i Albin Kohn tak uzasadniali decyzję przedruku traktatu: „My też nie zmieniliśmy w niczem tej drogiej pamiątki po ubiegłych czasach, pozostawiliśmy ją nietkniętą tak jak wyszła spod pióra tego autora, zmieniliśmy tylko druk gotycki na łaciński [...]. Ale zresztą wszystko jest nietknięte, nawet znaki pisarskie i ryciny pozostawiamy tak, jak były zrobione przed blisko trzysta laty. Chcemy bowiem [...] zachować, upowszechnić i ocalić od zguby to pomnikowe dzieło naszej ubiegłej przeszłości” (ibid.: 300-301).

4 Artykuł powstał z inspiracji Pana Profesora Mirosława Skarżyńskiego. Uważał On, że średniopolskie traktaty stawiarskie mogą być interesującymi obiektami badań ze względu na kształtujący się w nich dyskurs specjalistyczny z zakresu limnologii. Wprowadzeniem do tak postawionego zagadnienia badawczego jest niniejszy szkic dedykowany Panu Profesorowi.

5 Por. BP XXIX: 343; Kucharzewski 1897: IV, 1899: 7, 18; Łopaciński 1902: 338; PSB XLIV: 430. Przeprowadzona przeze mnie analiza interpunkcji w traktatach (por. Tutak 2018) świadczy o tym, że nawet jeśli Strojnowski przywłaszczył sobie fragmenty tekstu Strumieńskiego, to jednak znacznie je rozwinął i wzbogacił. Traktuję pracę Strojnowskiego jako przykład staropolskiej sylwy, czyli księgi domowej, w której gospodarz - stawiarz z zamiłowania - zapisywał porady związane z hodowlą ryb. Postanowił je wydać na początku XVII w., kiedy to nie istniało poczucie autorstwa $\mathrm{w}$ dzisiejszym znaczeniu. 
śladów obecności nadawcy przejawiającego się w tekście ze względu na odbiorcę. Pojęcie nadawcy rozumiem dość szeroko - jako podmiot czynności twórczych, który organizuje i porządkuje całą przestrzeń tekstową, wpływa także na jej kształt (typo)graficzny. W praktyce taką funkcję mogli pełnić nie tylko określeni biograficznie autorzy dzieła (O. Strumieński, S. Strojnowski), ale również impresorzy (Ł. Andrysowic, B. Skalski) czy nawet ich pomocnicy (anonimowi korektorzy, zecerzy).

Jak już wspomniałam, dzieła Strumieńskiego i Strojnowskiego należy zaliczyć do staropolskiego piśmiennictwa naukowo-użytkowego (Galilej 2017: 35) czy naukowo-dydaktycznego (Biniewicz 2011: 115), którego celem jest podanie czytelnikowi odpowiedniego zasobu wiadomości i opisu czynności praktycznych. Były one niezbędne przy urządzaniu gospodarstwa stawowego, jego prowadzeniu i dozorowaniu (Inglot, Nyrek 1960: 259). W związku z tym nadawcy obu dzieł jawią się jako osoby rozporządzające wiedzą praktyczną rozleglejszą niż odbiorca (por. Ficek 2013: 54). Taką pozycję zapewnia im pełniona funkcja, a zwłaszcza posiadane doświadczenie, o czym odbiorca zostaje poinformowany odpowiednio wcześnie, przed przystąpieniem do lektury tekstu głównego ${ }^{6}$, por. fragmenty dedykacji należących do obudowy paratekstowej traktatów?

[...] tedym też to wziął był przed się od kilku lat / w zabawie swej gospodarskiej / na której wielki czas wieku swego [...] strawiłem: żem to sobie dla pamięci w jedne Książki spisował / cokolwiekem godnego za częstem swem przypatrowaniem obaczywał / albo za ustawiczną Eksperiencyją dochodził. [...] Te tedy moje Książki albo raczej Terminacyję / gdy u mnie niektórzy przyjaciele moi widzieli / wiedli i namawiali mię do tego abych je miedzy ludzie wydał [...] tem mi dokuczali iż mi sie nie godzi tego pożytku zajźrzeć który by niektórzy mniej biegli gospodarze / z tego pisania mego choć niewystawnego wziąć mogli [...] (Strumieński 1573: $\left.\mathrm{A}_{2} \mathrm{v}-\mathrm{A}_{3} \mathrm{v}\right)$.

Bywając w Domiech W. ściów [...] w rozmowach tom był czasu niektórego przypomniał; żem o stawowym gospodarstwie, przestrogi niektóre z eksperiencyjej własnej / i z czytania też innych wzięte / częścią dla samego siebie / aby ich będąc słabej pamięci nie zabaczył / częścią dla synów moich / aby sie niemi na potym rządzili napisał (Strojnowski 1609: 305) ${ }^{8}$.

6 Również w tekście głównym nadawca potwierdza swoje kompetencje, por.: „Przydawało sie to mnie wszystko / i stąd umiem o tym powiedzieć” (Strumieński 1573: $\mathrm{O}_{2} \mathrm{v}$ ), „Jam sam tego doświadczył" (Strojnowski 1609: 358, 361, 362).

7 Na obudowę traktatu Strumieńskiego składają się: drzeworyt herbu Firlejów, tj. Lewart, dedykacja skierowana do Mikołaja Firleja oraz Zamknienie tych Książek, pełniące funkcję posłowia. Z kolei do elementów paratekstowych traktatu Strojnowskiego należy zaliczyć: dwa wiersze (inicjalny Adama Władisławiusza i finalny „imionoliter”: Stanisław Strojnowski - Staw Sławny Nosi Troski), przypisanie Andrzejowi Tęczyńskiemu i Zbigniewowi Lanckorońskiemu oraz przemowę adresowaną do syna Mikołaja.

8 Przykłady materiałowe podaję $\mathrm{w}$ transkrypcji, zachowuję natomiast zgodną z oryginałem interpunkcję i pisownię wielkich liter. 
Całość problematyki podejmowanej w traktatach została podzielona na rozdziały opatrzone tytułami, dobrze zapowiadającymi treść rozwiniętą w danym rozdziale ${ }^{9}$. Tytuły tych cząstek kompozycyjnych (powtórzone w żywej paginie) wyróżniono ozdobną frakturą, czyli czcionką gotycką większą niż utrwalony szwabachą tekst główny, który dalej dzieli się na akapity. W traktacie Strumieńskiego odpowiedni podział wspierają określone znaki typograficzne: paragrafu (znak ten wprowadzał segment tekstu dotyczący jednego wątku myślowego) oraz rączki (maniculae sygnalizowały ważne fragmenty tekstu). Taka precyzyjna i przemyślana kompozycja wypowiedzi potwierdza wysoki stopień kompetencji komunikacyjnych (Biniewicz 2011: 118) nadawców. Przekonanie to wzmacnia sposób ich przejawiania się w tekstach. Można stwierdzić, że nadawca, zwłaszcza w traktacie z 1573 r., wyłania się od czasu do czasu z tekstu, ale go sobą nie przesłania. Warto zwrócić uwagę na obecność form pierwszoosobowych w obu dziełach. W Stawach... nadawca dość rzadko ujawnia się w pierwszoosobowych formach werbalnych, por.:

Wszakoż uczynię w tej mierze śrzodek [...] (Strumieński 1573: $\mathrm{D}_{4}$ ).

[...] co to jest rzecz niepewna / i wielem stawów widał / przez takowe koryta potarganych [...] (ibid.: $\left.\mathrm{G}_{2} \mathrm{v}\right)$.

Przyrzekam ci / żeć sie już woda pod nie nie podbije (ibid.: $\mathrm{L}_{3}$ ).

Częściej formy 1. os. lp. pojawiają się w parentetycznych konstrukcjach, które odnoszą się do aktu pisania, np.:

A tak kiedy sie przyda robić robotę Dwułoktową / na wzwyż / Zakład i Zawierkę / jakom pisał (ibid.: $\mathrm{D}_{4} \mathrm{v}$ ).

A kiedy już ony żłoby włożysz tak jakom ci pisał co nagłębiej / Przebijże od nich Rów tak głęboki i szeroki jako ony żłoby są włożone (ibid.: $\mathrm{G}_{3}$ ).

To jest / uczyniwszy taką Grobelkę / jakom pierwej napisał / żeby to było miasto nadymacza (ibid.: N).

Zwrot jakom pisał pełni funkcję odesłania intratekstowego, kieruje uwagę odbiorcy w tył po linii tekstu. Co ciekawe, przywołany zwrot w wersji bezosobowej jako sie o tym wyższej napisało pojawia się w pierwszym zdaniu traktatu. Czy na tej podstawie można wyprowadzić wniosek o brakującym początkowym fragmencie dzieła

9 Por. tytuły rozdziałów dotyczących przyrządów pomiarowych. U Strumieńskiego: Napierwej o Wadze: albo o mierzeniu Stawów. Druga Waga na sznurze Blaszką. Wodna waga; u Strojnowskiego: O Korytku przez które dowiedujemy sie jaka przypadnie głębokość / albo szerokość zalewku w stawie / który kto budować ma. O Szynwadze. O Sklenicznej Wadze. O Sznurowej wadze. O Żuławskiej wodnej wadze. W obu traktatach tytuł najczęściej zawiera grupę przyimkową o + rzeczownik w Msc. Taki kształt przyjmuje 16 (na 21) i 26 (na 27) tytułów w pracy z 1573 i 1609 r. 
Strumieńskiego, o niekompletnej edycji Stawów... z 1573 r? Niestety, brak podstawy porównania, choć wiadomo, że w 1605 r. prasy Drukarni Łazarzowej opuściło nowe wydanie traktatu Strumieńskiego. Edycja tego dzieła została wprawdzie odnotowana w Bibliografii polskiej (BP 1933 XXIX: 342), ale nigdy jej nie odnaleziono.

U Strojnowskiego zwroty metatekstowe konsty tuowane przez verba scribendi pojawiają się rzadko, zastępują je zwroty z czasownikami mówienia, np.:

Ale sie im dziwować nie trzeba bo są na ziemi glinnej jełowatej tęgiej / na siwej albo czerwonej która chleba nie rada rodzi / i takowej gdziekolwiek groblą usypiesz / a zimy pełno stawek wody nabierze / chociaby descza nie było całe lato / bardzo mało wody ubędzie (jakom też pierwej powiedział) (Strojnowski 1609: 355).

[...] uczyń rów podle nich / a z każdej daj trąbę do rowu / jakom już powiedział (ibid.: 356).

$\mathrm{W}$ traktacie z $1609 \mathrm{r}$. nadawca ujawnia się w pierwszoosobowych wykładnikach intencji wypowiedzi, zwłaszcza w czasownikach performatywnych (radzenia i odradzania), por.:

[...] u takich stawków radzę aby były nie sczupłe groble / ale szerokie wedle potrzeby i wysokie wedle wody [...] (ibid.: 315 ).

Bywają też w stawiech albo i sadzawkach poniki / któremi woda ginie / meatem onym podziemnym gdzie indziej wypadając / tak że jej nigdy nie przybierze / i na to radę dam (ibid.: 356-357).

Kładą też drudzy wedle zwyczaju starych gospodarzów / miasto trąb koryta dłubane na cztery granie / a z wierzchu je przykrywają delami. Ja tak czynić nie radzę / bo to rzecz niepewna [...] (ibid.: 340).

W obu traktatach występują również formy werbalne w 1. os. lm. (my inkluzywne). Dzięki nim ten, kto mówi/pisze, może „solidaryzować się” z czytelnikami, budować wspólnotę doświadczeń i przekonań (Ficek 2013: 107), por.:

U nas w Polszce wiele Stawów nabudowano / a o tych Powroźcach nie słychali ani o Szychtach / i możemy sie bez nich obyć (Strumieński 1573: $\mathrm{F}_{4}$; Strojnowski 1609: 339).

Jest do tego gospodarstwo koło ryb nietrudne / wsadziwszy ryby do stawu [...] nie staramy sie czymbyśmy je karmili albo przechowali: na umniejszenie nam prace / sam Bóg je żywnością opatrza / my tylko łowiemy kiedy potrzeba / i używamy / a daj Boże aby z wdzięcznością (Strojnowski 1609: 314).

Przetoż czasów dzisiejszych takowe wymiatamy z stawów / a surowe okrągłe trąby kładziemy (ibid.: 341). 
Zarówno Stawy..., jak i Opisanie... reprezentują kompendia wiedzy aktywnej, w których nadawcy kierują do odbiorców rady, wskazówki i przestrogi. Tylko raz u Strumieńskiego pojawia się apostrofa Czytelniku mity („O tym wiedz Czytelniku miły”; $\mathrm{M}_{3} \mathrm{v}$ ), elementami identyfikującymi odbiorcę (Ficek 2013: 106) są określone formy werbalne, zwłaszcza konstytuujące wypowiedzenia dezyderatywne formy 2 . os. lp. trybu rozkazującego. Ich nagromadzenie sprzyja dynamizacji przekazu, por.:

A kiedy już będziesz miał kłaść ony żłoby / włożysz pierwej połowicę / a potym zasię drugą połowicę / słóżże je i zwierć przełożywszy mchem / a włożywszy fasuj dobrze około onych żłobów / ziemią a mchem przetrząsaj (Strumieński 1573: G-G $\mathrm{G}_{\mathrm{v}}$ ).

[...] uczyń tak: Przypatrz sie jako woda stoi w stawie przy krajach od czoła / i jako stoi na wierzchowinie / a przypatrzywszy / Daj brać przykopę na szerz jakobyś rozumiał żeć by woda zniosła / poczynając ją od wierzchowiska stawu / idźże z nią wszystko krajem wody ku młynowi podle stawu (Strojnowski 1609: 347).

W traktatach konstrukcje o charakterze dezyderatywnym zawierają również formy werbalne niefinitywne (bezokoliczniki) oraz finitywne z czasownikami modalnymi ${ }^{10}$ mieć $^{11}$, musieć, móc, potrzeba. Oto wybrane przykłady:

Krókiewka ma też być na nię urobiona / na której ma być Blejczyk ołowiany na cienkim sznurku albo na strunie zawieszony [...]. Krókiewka ma być na dłuż łokieć / i krótsza może być / ale nad łokieć dłużej nic (Strumieński 1573: $\mathrm{B}_{2}$ ).

A potrzeba tego pilnie strzec kto Wagi pilnuje / aby oni dwa co Synwagę trzymają nie opuścili wagi (ibid.: $\left.\mathrm{B}_{2} \mathrm{v}\right)$.

Ten słup ma być ociosan na Czterzy grani / i urobić go jako koryto / i wpuścić go jednym końcem w słup / czopem dobrze mocno wbić na Mech. Potym Stawidła weń stawić [...]. Potym od spodku ziemią go dobrze zasuć / a przed tym zaś słupem wykarbować [...] (ibid.: $\left.\mathrm{G}_{4}\right)$.

A jeśliby u rzeki były wysokie brzegi / musisz wodę podnieść jazem. [...] tam możesz młyn zbudować / u którego mogą być koła korzeczniki na pięć stóp (Strojnowski 1609: 329).

Wymienione wykładniki modalne (morfologiczne i leksykalne) wyrażają postawę wolitywną i oceniającą nadawcy (por. Grzegorczykowa 1973: 203) - z zaleceniem

10 Tzw. czasowniki modalne wyrażają subiektywną (zależną od nadawcy wypowiedzi) lub obiektywną (niezależną od mówiącego) konieczność albo możliwość zajścia jakiegoś zdarzenia.

11 W omawianych traktatach grupa werbalna mieć + bezokolicznik wyraża modalność deontyczną (o innych interpretacjach tej grupy w związku z ewidencjalnością i prospektywnością por. np. Topolińska 1968; Nowakowska 2017), przy czym deontyczne znaczenie czasownika mieć jest bliższe 'spodziewania się' czy 'planowego zadania' niż znaczenia 'konieczności' (musieć) (Nowakowska 2017: 227). 
łączy się ocena stanu rzeczy. Ów stan jest wartościowany pozytywnie przez nadawcę ze względu na (przewidywaną) korzyść odbiorcy. Nadawca próbuje przekonać o tym odbiorcę, podaje uzasadnienie zalecenia, tym samym łagodząc jego wymowę. Jak pisze Jerzy Biniewicz:

Odbiorca zatem - jako osoba merytorycznie podporządkowana nadawcy, której zaprojektowano ścieżkę analizy, dochodzenia do konkluzji - powiadamiany jest o skutkach podjętych działań, przewidywanych wynikach, które niejednokrotnie mają charakter niepodważalnych konstatacji, lub o potrzebie realizacji określonego scenariusza poczynań czy też konieczności przyjęcia określonej wykładni referowanych kwestii (Biniewicz 2013: 260).

Por.:

[...] układaj miąższe końce za każdy kół na łokieć / a patrz żećby końce szły równo. A kiedy już ułożysz warstę jednę od końca do końca Groblej / zasypże ją na wierzchowiska tego chróstu. [...] także sie już sprawuj aż do końca / wszystko kładź warstę przeciw warście. Zową taki Taras Cynowatym. A kiedy go uczynisz jako sie pisze / uznasz iż taki dobry (Strumieński 1573: $\mathrm{H}_{2} \mathrm{v}-\mathrm{H}_{3}$ ).

Kiedy masz Upustę zakładać / nie budujże jej nigdy we śrzodku Groblej / ale jej patrz miejsca w końcu Groblej. Abowiem kiedy będzie Upusta w śrzodku Groblej / a zerwie sie / tedy już wszystko wypadnie z Stawu (ibid.: $\mathrm{L}_{2}$ ).

A chceszli abyć staw dobrze chodził / włóż trąby głębiej niż dno jego / bo łatwiej stawidła albo czopu nie wybierać / niżeli w wodzie głęboko ryb szukać (Strojnowski 1609: 339).

Przedstawiony w traktatach wywód odwzorowuje przebieg procesu myślowego nadawcy, który dąży do przystępnego przekazania czytelnikowi wiedzy z zakresu gospodarki stawowej. Na ten wywód zostaje nałożona sieć leksykalnych wykładników spójności wypowiedzi, które pomiędzy segmentami tekstu sygnalizują związki polegające na uzasadnianiu, wyjaśnianiu, uściślaniu, uzupełnianiu czy przeciwstawianiu, por::

Tu tedy wiedzieć potrzeba: Że Pan Bóg grunty któremi woda bieżeć miała tak odcerklować i odmierzyć raczył / że są schodziste i pochyłe: przetóż wszystkie strumienie które do rzek bieżą / i wszystkie rzeki które do morza wpadają / muszą też mieć swoje pochyłość [...] (ibid.: 316-317).

Ale kiedy Grobla wielka / tedy też ma być Grundfest więtszy: to jest wzgłąb łokci trzy / a na szerz łokci czterzy (Strumieński 1573: $\mathrm{E}_{3}$ ).

Korytkowy ten instrument / pamiętam że w Niemczech misternie osadzony i przyprawiony bywa: ale iż tam daleko poń posyłać / a w Polscze o ślósarza któryby go zrobić umiał trudno / przetoż inszy sposób urobienia jego opiszę (Strojnowski 1609: 319). 
Podobnie działają konstrukcje metatekstowe odsyłające wstecz lub w przód po linii tekstu. Sterują one uwagą odbiorcy w ten sposób, że przypominają lub zapowiadają określone „porcje” wiadomości przedstawione w odpowiednich segmentach wywodu, por.:

[...] niechajże robią na Pręty w nich / Pręt na pręcie Aże jakoć będzie potrzeba na głębią: wszak już masz na Przodku naukę o Pręciech / jakie mają być i po jakich pieniądzach mają być robione (Strumieński 1573: $\mathrm{N}_{4}$; Strojnowski 1609: 356).

Kiedy już obaczysz do onego stawu dobre wzięcie wody który masz wolą budować / tedy Staw możesz zacząć. A to tym sposobem: Rozmierz sobie onę Groblą tego stawu na sztuki [...] (Strumieński 1573: D v; Strojnowski 1609: 330).

Jeszcze o tym więcej trzymam / Wybrawszy łoże Upustowi wedle potrzeby / ułóż chróstem pięknym długim Brzozowym / albo Choiną równiuchno warstwę [...] (Strumieński 1573: $\mathrm{M}_{4}$; Strojnowski 1609: 354).

W planie elocutio oraz dispositio wypowiedzi nadawcy występują określone środki leksykalne wsparte znakami interpunkcyjnymi (por. Tutak 2018). Działają one jak drogowskazy, tzn. „prowadzą” odbiorcę - adepta sztuki stawiarskiej - przez tekst, służą temu, by zrozumiał wywód i przyswoił go, a także zapamiętał wskazówki, rady, przestrogi dawane przez mistrza stawiarskiego. Funkcji mnemotechnicznej jest też podporządkowany paralelizm semantyczno-składniowy członów tworzących zestroje, połączonych stosunkiem współrzędności lub podrzędności (por. Kalicki 1965), por.:

Pierwszego Roku siej Proso / Ber / Mannę / Jęczmień. Drugiego Roku / siej Żyto / Pszenicę. Trzeciego Roku także. Czwartego możesz siać Owies (Strumieński 1573: $\mathrm{L}-\mathrm{Lv})$.

A tak każdy jeśli sie waży Staw zbudować: ważysz sie tego / Sadzawki sobie pobudować / abyś miał kędy ryby wsadzić czasu Spustu / i chować. W jednej Karpie więtsze / w drugiej mniejsze / w trzeciej namniejsze: w drugich Szczuki / Okunie / albo i wszelakie Ryby brakując je sobie (ibid.: $\mathrm{N}_{3}$; Strojnowski 1609: 355).

Tych szychet w powróźcu cztery: A w powróźcu łokci Morawskich / które w Rusi zową Arsinmi czterdzieści i cztery. I tak sie z temi szychtami i powróźcami sprawują / jako u nas z laską (Strumieński 1573: $\mathrm{F}_{4}$; Strojnowski 1609: 339).

Wspomniałam już, że celem komunikacyjnym nadawców traktatów było przekazanie wiedzy w sposób przystępny, dostosowany do możliwości percepcyjnych odbiorców niespecjalistów. Warto odnotować, że odbiorcami traktatów mieli być adepci sztuki stawiarskiej, gospodarze, którzy zdecydowali się na założenie stawu rybnego. O tym, że traktaty nie były adresowane do fachowców stawiarzy, świadczy sposób ich przedstawienia w tekście, por.: 
Zda sie też więc czasem / że równo robią albo ziemię biorą / ale jednak ty nie leń sie chodząc po robocie / kędy ujźrzysz wodę albo kupę chrustu / macać dołów laską / bo stawiarz chytry / uczyniwszy dół napuści wen wody / a ty prostaku będziesz mniemał aby tu równo było / i nie obaczysz aż na spuście / kiedy psi albo wrony będą ryby zmykały (Strojnowski 1609: 336).

U Strumieńskiego w segmencie odpowiadającym przytoczonemu fragmentowi nie pojawia się wprawdzie figura chytrego stawiarza, ale i w tym traktacie zawodowi stawiarze nie są partnerami aktu komunikacji, por.:

Aczci sie też czasem zda że równo robią / albo ziemię biorą: ale sie ty nie leń chodząc po robocie kędy uźrzysz wodę albo kupę chrustu / macaj laską dołów. Bo oni [robotnicy - K.T.] uczyniwszy dół / i napuści weń wody / a ty prostaku będziesz mniemał / aby tu równo było / i nie obaczysz tego / aże na spuście kiedy będą ryby wrony albo psi zmykali (Strumieński 1573: $\mathrm{E}_{4}-\mathrm{E}_{4} \mathrm{v}$ ).

Napierwej kiedy już stawarz uczyni Grundfest / niechajże go zawiezie dobrą ziemią niebagnistą [...]. A kiedy już pożenie robotę ku Górze to jest Groblą / pilnujże z pełnali zakład / dobrzeli Surem idzie: wynidzieli mu też zawierka wedle miary. I potrzeba mu to często przemierzać / przed tym niźli wystawi: nie w ten czas kiedy już roboty dokończy (ibid.: Fv).

W omawianych traktatach występuje słownictwo specjalistyczne związane z zakładaniem stawów i hodowlą ryb - rodzime, jak: gościnna/gościa woda, grobla czelna, izbica, kościenek, krokwica, młyn korzeczny, nadymacz, odrost, piątniki, pobocznica, policzek, póniki, prętna robota, przekopa, przykadek (u Strojnowskiego), skrzynia, słup, spust, stawidło, suć grobla, tarlisko, upust(a), walnik, włok, wzbierek wody, zawierka, zwieranie groblej, zwódnica, żłób (u Strojnowskiego trąba); a także obcego pochodzenia, zwłaszcza zapożyczenia z języka niemieckiego: baszta, bórta, (wy/za)bórtować, (pod/u)fasować, flaga, fuga, grundfest, karbować, regiel, synwaga (u Strojnowskiego szynwaga ${ }^{12}$ ), szpóntal, szychta, us(z)tosować stosyglem itd. W traktacie Strumieńskiego dość konsekwentnie terminy te utrwalono wielką literą, natomiast ich objaśnienia w obu dziełach pojawiają się sporadycznie, por.:

[...] napierwej mianuj Zamek albo jako oni zową Grundfest [...] (Strumieński 1573: $\mathrm{E}_{2} \mathrm{v}$; Strojnowski 1609: 335).

Zasię na wierzchu od Pala do pala włożyć zaczopowawszy pal / Ogniwa dębowe / zową to Reglmi (Strumieński 1573: $\mathrm{K}_{2} \mathrm{v}-\mathrm{K}_{3}$ ).

12 Na fakultatywną postać terminu synwaga u Strumieńskiego / szynwaga u Strojnowskiego zwrócił uwagę Feliks Kucharzewski, autor broszury poświęconej dawnym narzędziom niwelacyjnym (1899: 9-10). Określił śródwagę jako „prostą ośmiołokciową łatę z przymocowaną do niej małą gruntwagą" (ibid.: 7). 
Na wierzchu zasie od pala do pala zaczopowawszy włożyć ogniwa albo regle dębowe

[...] (Strojnowski 1609: 349).

[...] bijże pod ony Przyciesi i Policzki / Szpóntale / zową to po staroświecku Lemięsze

/ tak je głęboko bij / aże już dalej nie będą postępowały w ziemię (Strumieński 1573:

$\mathrm{L}_{3}$; Strojnowski 1609: 352).

Porównajmy opis funkcjonowania śródwagi w obu traktatach. W Stawach... nadawca uznaje ją za nasprawiedliwsza, przy czym formułuje warunek: kto niq z pamięcia waży. Po takiej zapowiedzi przechodzi do sposobu jej urobienia, por.:

Ta Synwaga tym obyczajem ma być urobiona. Z suchej Tarcice Jodłowej / na dłuż

Ośm’ łokci kupieckich: a na szerz pół czwierci (Strumieński 1573: Bv-B 2 ).

U Strojnowskiego śródwaga pojawia się dopiero po opisie funkcjonowania korytka wodnego i z zastrzeżeniem, że jednak z więtsza praca rozmierzać nia przychodzi. Następnie nadawca charakteryzuje śródwagę, „definiuje” ją, por.:

A Szynwaga jest sztuka tarcice jodłowej / na dłuż ośm łokci kupieckich / wszerz na pół ćwierci (Strojnowski 1609: 323).

Nadawcy traktatów uznają słownictwo specjalistyczne za mniej lub bardziej znane odbiorcy, w każdym razie za wystarczająco przyswojone i w związku z tym umożliwiające sprawną i skuteczną komunikację między mistrzem i adeptem sztuki stawiarskiej. Skromne eksplikacje mają podtrzymać tę interakcję i doprowadzić do tego, by odbiorca „zawierzył” nadawcy i postępował zgodnie z podanymi przez niego wskazówkami. Twórcy traktatów mają świadomość tego, że choć gospodarka stawowa jest naosobliwsza nazmyślniejsza i napożyteczniejsza (Strumieński 1573: A ), to jednak jest dość trudna, wymaga uwagi, wiedzy i zapału. Dlatego stopniują poziom trudności zadań czy poleceń do wykonania, por.:

Aczci na ty Pręty robota pobożna i spora / jeno kto by jej nie rozumiał koło odbierania tych Prętów / prędko sie sam oszuka. Ale kto by prawie dobrze wyrozumiał dobra jest: Wystawi sześcią Prętów sztukę na wzwyż łokci czterzy. Ale kto by nie rozumiał / niechaj robi na sztuki / bo łatwiejsza (ibid.: $\mathrm{F}_{3}-\mathrm{F}_{3} \mathrm{v}$; Strojnowski 1609: 339).

Czynią to ludzie rozmaitym obyczajem / jedni ubiwszy z chróstu mocno kosz / wprawi w słupy mocno żłoby / wbije też Stawidła w słupy / i zasypie ziemią [...]. I tego nie ganię / a zwłaszcza prostak chciałby co uczynić foremnie a bez rozumu lepiej że tak czyni jako rozumie (Strumieński 1573: $\mathrm{G}_{3}-\mathrm{G}_{3} \mathrm{v}$; Strojnowski 1609: 342).

Aby uczynić przekaz łatwiejszym w odbiorze, nadawca proponuje czytelnikowi kilka rozwiązań. Passusy istotne dla zrozumienia całości wywodu zawierają metatekstowe zwroty i wyrażenia potwierdzające tę ważność, np.: 
I kiedy obaczysz że sznurek równo bije / od dziurki do dziurki / i zakrywa Rezę / o tym wiedz / że już pewna waga / już możesz z nią na pewne kazać [...] (Strumieński 1573: C).

A na to też miej baczność / żebyś kazał żłób robić od cienkiego końca im dalej tym szerzej aż do końca (ibid.: $\mathrm{G}_{4} \mathrm{v}$ ).

Przetóż miej to na dobrej pamięci / w tym rozmierzeniu i upatrowaniu pochyłości gruntów / czynić znaki na laskach / łokcie karbować albo je pisać. A to proba najpewniejsza wracając sie ze sznurem / albo i z każdym instrumentem z tych tu pomienionych / jeśli sie waga trafia w one znaki / któreś pierwej natknął i karbował (Strojnowski 1609: 327).

A jeśliby tu kto pomyślał / czemu ty sztuki w tak wielki szacunek idą / wiedz że tak być musi / bo już grobla mięższa i wyższa / daleko sie ziemia od groblej odebrała [...] (ibid.: 333).

W Stawach... pojawiają się trzy rysunki przyrządów pomiarowych (na stronach $\mathrm{B}_{2}, \mathrm{~B}_{4}$ v i $\mathrm{C}_{3}$ ), w Opisaniu... element ikonograficzny występuje jeszcze częściej, dotyczy nie tylko urządzeń mierniczych, ale także sposobu pomiaru powierzchni gruntu przeznaczonego na staw i jego poziomu oraz budowy i ulokowania urządzeń specjalnych, jak trąba ze słupem (Strojnowski 1609: 343) czy izbica (ibid.: 344). Wszystkie rysunki zostały u Strojnowskiego ponumerowane i oznaczone jako Figury (1-11). Wreszcie wyłącznie w Stawach... nadawca wprowadza zabezpieczenie komunikacyjne w postaci przekazów odsyłających do konkretnych obiektów, wytworów kultury materialnej, które są przedmiotem analizy (Biniewicz 2011: 117), por.:

Wszakże o tych Basztach więcej pisać nie będę: kto sie im chce przypatrzyć a takowego cieśle który by je umiał budować / tedy go najdzie w Czernichowie / w Niepołomicach u pana Morskiego etc. (Strumieński 1573: $\mathrm{G}_{3} \mathrm{v}$ ).

A w niektórych krajoch i murowane Tarasy murują. Czego jeśli sie napatrzyć chcesz / idź do Morawy do Czech / a zwłaszcza kędy nieboszczyk Pan z Persztyna trzymał (ibid.: $\mathrm{G}$ [popr. $\mathrm{H}] \mathrm{v}-\mathrm{H}_{2}$ ).

Nad tą też skrzynią / możesz wziąć wodę / do czegoć by jeno była potrzeba / jakom już o tym pisał. A jeślibyśs nie rozumiał tu w tej skrzyni pisaniu mojemu / Tedy najdziesz taką w Babicach u stawu Szczeglickiego i u Niegrowskiego (ibid.: $\mathrm{K}_{3}$ ).

Warto zauważyć, że w obu traktatach w rzeczowy wywód niekiedy zostają wplecione dygresje dotyczące zachowania ludzi pracujących w gospodarstwie stawowym. W krótszych (por. O Stawiech Ruskich ${ }^{13}$, ibid.: $\mathrm{K}_{3} \mathrm{v}$; Strojnowski 1609: 350) lub

13 „I kiedy Staw spuszcza / tedy go przekopuje / ma wielką fortunę że mu Ryby nie wynidą z wodą. Więc posadzi chłopa $\mathrm{z}$ chabiną / u przerwy / aby kiwał / mniema by sie to jego kiwania Ryba bała. 
dłuższych (np. O Upustach rozmaitych ${ }^{14}$, Strumieński 1573: L L-M; Strojnowski 1609: 352) scenkach rodzajowych pojawiają się akcenty humorystyczne, które stanowią dobry „przerywnik” w trudnym wykładzie sztuki stawiarskiej. U Strojnowskiego elementy narracyjne występują jeszcze częściej niż w Stawach..., zaburzając linearny przebieg wywodu. Nadawca przeplata opis metod i zasad hodowli ryb anegdotami i sentencjami, które przez swój dygresyjny charakter zbliżają sposób przedstawiania treści do szlacheckiej gawędy, por.:

[...] jest recreatia jedna i delicyje wzrokowi naszemu patrzyć na stawy / przetoż i Medykowie pojźrzenia na wody kładą między widziadła oczom zdrowe i pożyteczne / dla podobienstwa które mają oczy z wodami / bo są oboje przeźroczyste i jasne. Tym względem Arystoteles Aleksandra wielkiego ucząc / rozkazował też jemu aby na wodę przeźroczystą zieloną często patrzył (Strojnowski 1609: 314).

I Boże daj to / aby Professorowie w Akademiach naszych chcieli naśladować Platona / który do swej szkoły żadnego nie przypuszczał / kto by nie był ćwiczony w Geometryjej: Przez tę doszli niektórzy jak wielki jest okrąg ziemie / jak wielki słońca / jaka jest odległość od ziemie do nieba miesięcznego / a jest to nauka omylności w sobie nie mająca (ibid.: 318).

[...] pospolicie mówią i często sie tak trafia: Że skąpy dwa razy kupuje / a leniwy dwa razy robi (ibid.: 332).

Bo Niemiec powiada: gnau gerechnet und wol bezalt bahelt lange franschaft / to jest / skromnie targuj / a dobrze zapłać / to długą przyjaźń zachowuje (ibid.: 333).

Traktaty stawiarskie musiały się cieszyć wielką popularnością wśród odbiorców, skoro zostały właściwie „zaczytane”. Zygmunt Gawarecki i Albin Kohn w 1861 r. uznali Opisanie... za „wielką rzadkość bibliograficzną”, bo jak uzasadniali, „trzy tylko stare egzemplarze tego dzieła przechowały się dotąd na całej przestrzeni dawnej Polski” (Gawarecki, Kohn 1861: 299). O popularności traktatów zadecydował nie tylko popyt na szerzej dostępną literaturę fachową z zakresu gospodarki rybnej, ale i sposób prezentacji treści, kształtowania argumentacji, gruntownie przemyślana i konsekwentnie przeprowadzona organizacja przestrzeni tekstowej. Ważną rolę na tym polu odegrały także wykładniki strategii nadawczo-odbiorczej, a właściwie wykładniki relacji zachodzących między znawcą sztuki stawiarskiej i jej adeptem. Warto zauważyć, że owe wykładniki są w obu traktatach podobne. Nadawca ujawnia się w formach pierwszoosobowych i kieruje do odbiorcy rady, wskazówki i prze-

Ale to wiedz / kiedy już Ryba wskoczy na prąd / by i sam chłop wskoczył / tedy jej już nie zabroni: i narzeka potym chłop ten który Staw kupi / Upuściłem Rybę".

14 Por. fragment: „A kiedy Lato przyjdzie / będzie sie frasował że niedobre Zboże / wstąpi do Karczmy / uskarża sie przed chłopy / że Zboże złe: a chłopi tam już z niego będą szydzić / będą go cieszyć: Nie staraj sie panie Starosta / będzieć dalibóg dobrze / nada-ć sie jeszcze Zboże: a jeśli nie Zbożym / tedy sie nagrodzi Stokłosą" (Strumieński 1573: $\mathrm{L}_{4} \mathrm{v}$ ). 
strogi, konstytuowane przez finitywne i niefinitywne formy werbalne, zwłaszcza czasowniki w 2 os. lp. trybu rozkazującego. Odbiorca jest w analizowanych tekstach traktatów tą instancją komunikacyjną, która odgrywa znaczniejszą rolę niż nadawca. Sposób zorganizowania i uporządkowania przestrzeni tekstowej służy dobru odbiorcy, temu, by przyswoił on i zapamiętał wiadomości około Stawowych robót I i około miary i ważenia ich / albo narybienia ich (Strumieński 1573: $\mathrm{Q}_{3}$ ).

\section{Źródła}

Strojnowski S., 1609, Opisanie porządku stawowego..., Kraków; przedruk w: Z. Gawarecki, A. Kohn, Polskie stawowe gospodarstwo, Warszawa 1861, s. 303-365.

StrumieŃski O., 1573, O sprawie sypaniu, wymierzaniu i rybieniu stawów..., Kraków, [on-line:] http://www.dbc.wroc.pl/dlibra/doccontent?id=3351.

\section{Literatura}

BAlCERZAn E., 1999, Nowe formy w pisarstwie i wynikające stąd porozumienia, [w:] J. Kozielecki (red.), Humanistyka przełomu wieków, Warszawa, s. 358-38o.

Biniewicz J., 2011, Rodzenie się polskiego dyskursu naukowego. Pragmatyka, struktura i język traktatu Olbrychta Strumieńskiego O sprawie, sypaniu, wymierzaniu y rybieniu stawów, [w:] D. Ostaszewska, J. Przyklenk (red.), Gatunki mowy i ich ewolucja, t. 4: Gatunek a komunikacja społeczna, Katowice, s. 111-122.

BINIEwicz J., 2013, Początki polskiego piśmiennictwa naukowego, technicznego - relacje komunikacyjne zarysowane w tekstach, "Colloquia Anthropologica et Communicativa” 6, s. 249-262.

BP: Bibliografia polska Karola i Stanisława Estreicherów, cz. 3, Kraków 1891-2007.

Dobrowolski K.A. (red.), 1995, Przyrodniczo-ekonomiczna waloryzacja stawów rybnych $w$ Polsce, Warszawa.

FICeK E., 2013, Poradnik. Model gatunkowy i jego tekstowe aktualizacje, Katowice.

GALILEJ C., 2017, XVII-wieczny poradnik rolniczy. Lingwistyczna charakterystyka gatunku (na przykładzie traktatów agronomicznych Jakuba Kazimierza Haura), „Prace Językoznawcze" XIX, z. 4, s. 31-63.

Gawarecki Z., Kohn A., 1861, Polskie stawowe gospodarstwo, Warszawa.

GrZEgorCZYKowA R., 1973, Czasowniki modalne jako wykładniki różnych postaw nadawcy, [w:] J. Burian (red. nacz.), Otázky slovanské syntaxe III. Sborník symposia „Modální výstavba výpovédi v slovanských jazycích” Brno 27-30 záři 1971, Brno, s. 201-204.

Inglot S., NyReK A., 1960, Jana Dubraviusa i Olbrychta Strumieńskiego dzieła o gospodarce rybnej. Studium porównawcze, [w:] E. i K. Maleczyńscy (red.), Studia z dziejów polskich i czechosłowackich, t. 1, Wrocław, s. 249-282.

Kalicki T., 1965, Z zagadnień składni retorycznej, „Zeszyty Naukowe Uniwersytetu Jagiellońskiego. Prace Językoznawcze" nr 15, s. 211-254. 
Kucharzewski F., 1897, Przedmowa, [w:] idem (wyd.), Olbrychta Strumieńskiego O sprawie, sypaniu, wymierzaniu i rybieniu stawów 1573, „Biblioteka Pisarzów Polskich”, nr 35, Kraków, s. III-V.

Kucharzewski F., 1899, O narzędziach niwelacyjnych używanych $w$ Polsce $w$ XVI wieku, Warszawa.

ŁopaCıŃsKi H., 1902, Przyczynek do historyi plagiatów w piśmiennictwie polskiem. - Kto byt autorem „Bylicy Świętojańskiej”?, „Pamiętnik Literacki” I, s. 265-275.

Nowaкошsка M., 2017, Interpretacja prospektywna peryfrazy <mieć + bezokolicznik>, „Biuletyn Polskiego Towarzystwa Językoznawczego” LXXIII, s. 221-246.

Nyrek A., 1987, Przedmowa, [w:] O. Strumieński, O spráwie, sypániu, wymiérzániu i rybieniu stáwów, tákże o przekopách, o ważeniu i prowádzeniu wody. Książki wszystkim gospodarzóm potrzebné, oprac. K. Kwaśniewska-Mżyk, Opole, s. V-XXXII.

PSB: W. Konopczyński i in. (red.), Polski słownik biograficzny, t. I-LI, Kraków 1935-.

Topolińska Z., 1968, Miejsce konstrukcji z czasownikiem „mieć” w polskim systemie werbalnym, „Slavia Orientalis” XVII, z. 3, s. 427-431.

TuтAк K., 2018, O dwukropku w dawnym piśmiennictwie użytkowym (na przykładzie traktatów stawiarskich Olbrychta Strumieńskiego i Stanisława Strojnowskiego), „LingVaria” nr 2 (26), s. 141-155, https://doi.org/10.12797/LV.13.2018.26.10.

\section{Sender-Recipient Instances in Treatises on Ponds from the $16^{\text {th }}$ and $17^{\text {th }}$ Centuries Summary}

The paper discusses the ways in which sender-recipient strategy is realized in old treatises on pond economy. It focuses on the indices of textual relations between the master of the pond art and the student. The analysis has shown that in both treatises, the recipient is that communicative instance which plays a much more significant role than the sender. The organization and arrangement of the textual space serves the good of the recipient. The sender employs for this purpose desiderative constructions, lexical indices of cohesion of the utterance, and semantic-syntactic parallelism of elements. The authors of the treatises skilfully include an iconographic component in their lecture; Strumieński even refers to specific objects in the extra-linguistic reality. 